UDK 658.8:005.725

https://doi.org/10.18485/union_pf_ccr.2021.ch3

Prof. Tibor Tajti (Thaythy)(C*

\title{
MULTI-LEVEL MARKETING AND PYRAMID SCHEMES
}

\begin{abstract}
Multi-level marketing is one of those business concepts that has become popular virtually in all European post-socialist systems at the beginning of their transition towards market economies; including the Western Balkans. Although hundreds of consumers have become members of their variants, and many have also suffered losses within a short time span, this has occurred virtually unnoticed by the local lawmakers. Hardly has the regulatory inertia been changed by now save the countries that have in the meantime acceded the European Union that possesses the "4Finance UAB" test to differentiate legitimate MLM ventures from disguised pyramid schemes quite similarly to the earlier 'Amway Test' of the Federal Trade Commission of the United States. Besides presenting these topics and filling a gap in legal scholarship, the article reflects on the reasons why more attention should be devoted to these developments by regulators being sensitive to the collective rights of consumers.
\end{abstract}

Key words: multi-level marketing (MLM), pyramid schemes, naked pyramid schemes, Ponzi schemes, financial regulation, consumer protection, Amway test, '4finance UAB' test, European Union law.

\section{INTRODUCTION}

This article is focused on multi-level marketing (MLM), a new popular form of direct sales involving hundreds if not tens of thousands of consumers being increasingly present on all continents, even in fledgling economies, and yet which also generates a number of legal challenges that no regulator should neglect. Online MLMs and pyramids, further intensify these problems. This applies especially to the nexus of MLMs and illegal pyramid schemes. The paper is a comparative piece of writing, ${ }^{1}$ desiring also to fill the gap in pertaining legal scholarship on the Western Balkans, and beyond. The central thesis is that targeted sector-specific regulation would be beneficial not only to consumers

* Professor of law at the Legal Studies Department of Central European University - Private University, Vienna, Austria. Contact: tajtit@ceu.edu. The author would like to express his thankfulness for the exchanges related to MLM in Serbia to attorney Petar Kojdić (Schönherr, Belgrade office, Serbia) and ass. professor Slobodan Vukadinović (University Union, Belgrade, Serbia).

1 For a lege lata analysis see Varga, S., Pravni aspekti mrežnog marketinga i zabrana piramidalne trgovine, in: Mićović, M. (ed.), 2014, XXI vek - vek usluga i uslužnog prava, Kragujevac, Pravni fakultet, pp. 57-75. 
becoming members of these but for the Serbian, and other similarly situated economies as well. The fledgling MLM sectors should not frown at this idea either because a properly balanced regulatory framework would benefit them as well as it would help cast a more favorable light on the industry.

\subsection{WHY SHOULD THE TOPIC BE OF IMPORTANCE IN SERBIA?}

Notwithstanding the dearth of not only publications from under the pen of legal scholars but also of empirical evidences, MLM is present in the country; best proven by various internet sources. ${ }^{2}$ As in other countries, from the United States as the cradle of the business model through to India or South East Asia, one can easily find both industry publications promoting it $^{3}$ and blogs warning consumers against the corollary vices. ${ }^{4}$ As far as Serbia is concerned, according to an internet source more than fifteen such ventures are already in the country, including such international mammoths as the US Herbalife, the Swiss-Austrian Lyoness ${ }^{5}$ to a number of less-known ones. ${ }^{6}$ One would not err either claiming that while the names of such giant internationally present MLM corporations as AVON, AMWAY, or TUPPERWARE, would ring the bell in the ears of many citizens in the countries of Western Balkans, most of them would not really know what is exactly at stake. It should not come as a surprise either that the names of quite of a number of other MLM systems are completely unknown in the region. ${ }^{7}$ In other words, the business model is already here, just like many of the globally renowned brands and the linked regulatory dilemmas, and further new developments are to be expected in the near future.

It may be less known and hardly recorded that MLMs had, in fact, appeared in the country shortly after the former Yugoslavia chose to step on the path toward market economies, capitalism, which entailed also trade liberalization and gradual opening the doors to new legal and business concepts. The concept and business model of MLM being unbeknownst to me, I attended, for example, an Amway promotion session in the apartment of a cognizance and have purchased

2 See, e.g., Pavlović, I., Multilevel marketing, kad se podvuče crta, in daily 'Politika', 22 October 2016 issue available electronically at http://www.politika.rs/sr/clanak/366121/Pogledi/Multilevel-marketing-kad-se-podvuce-crta, accessed 5 September 2020.

3 See e.g. the website of LR LIFETAKT at https://www.mpshop.rs $/ \mathrm{hu} / \mathrm{mlm} /$ accessed on $1 \mathrm{Sep}-$ tember 2020.

4 See e.g. the website of 'Anti-MLM Serbia' at https://mlmprevara.wordpress.com $/ \mathrm{mlm}$-istinei-zablude/ accessed 1 September 2020. The website seems to be run by an anonymous host.

5 Lyoness was, according to the available data, founded in Graz, Austria, but now its headquarters are in Switzerland. Its website is at https://www.lyoness-corporate.com/en/ accessed 5 September 2020.

6 See Kompanije mrežnog marketinga koje posluju u Srbiji at https://mlminternetposao. wordpress.com/2018/03/24/kompanije-mreznog-marketinga-koje-posluju-u-srbiji/ accessed 1 September 2020.

7 For the list of and brief introduction of the top forty MLM companies globally see Nagrale, Pritam, 40 Top MLM Companies in the World at https://moneyconnexion.com/mlm-companies-in-the-world.htm accessed 5 September 2020. 
some products (vitamins) through the California Fitness back then somewhere at the end of the 1980s in Serbia.

Other than these exposures more than thirty years ago, I am, neither part of any MLM system, nor am a member of any organization or initiative working on their prohibition. ${ }^{8}$ As visible from this paper as well, my interest in MLMs is exclusively of academic nature and primarily because of the fact that pyramid and Ponzi schemes as peculiar forms of financial fraud especially hardly hit emerging financial systems. It is important to stress this because the stance toward MLM as a phenomenon available both, in online and offline publications, radically differs depending exactly on one's involvement or experiences with MLMs. As often is the case, objectivity is somewhere in-between the two extremes as it should be visible from the ensuing elaboration.

\subsection{WHAT IS WHAT?}

\subsubsection{What is a Multi-Level Marketing?}

The history and the phenomenon of MLM is both interesting and complex, canvassed already by quite a number of publications though not necessarily stemming from under the pen of lawyers. ${ }^{9}$ As marketing scholars put it, besides door-to-door selling, it was MLM that revolutionized face-to-face selling, offering something brand new, the "business opportunity" that "altered single-level, commission-based traditional direct selling." ${ }^{10}$ Historically, the predecessors of MLM are, on the one hand, the $19^{\text {th }}$ century peddlers travelling long distances in the US offering primarily non-branded products to customers, and in the next phase, the door-to-door salesman already being characterized by selling branded products, from cooking utensils, furniture and later TV sets. ${ }^{11}$

Although some of the US MLM giants have been founded already close to the end of the $19^{\text {th }}$ or early $20^{\text {th }}$ century,,$^{12}$ the birth of the MLM industry, or switching to the business model known also today, in the US is rather dated to the 1940s. ${ }^{13}$ Yet the true heydays of MLM began somewhere in the second half of the 1960s. ${ }^{14}$ The new marketing model lowered the fixed costs primarily by shifting the costs of recruitment of new members, their training and supervision

8 See, e.g., the website of the AntiMLM Coalition at https://mlmtruth.org/ accessed 5 September 2020 .

9 For a succinct overview of the US history of MLM see Keep, W. W., Vander Nat, P. J., 2014, Multilevel Marketing and Pyramid Schemes in the United States: An Historical Analysis, Journal of Historical Research in Marketing, 6, pp. 188, 195, at 189. [Hereinafter: Keep, W. W., Vander Nat, P. J., 2014]. See also Friedman, W. A., 2004, Birth of a Salesman: The Transformation of Selling in America, Harvard cited often by Keep \& Vander.

10 Keep, W. W., Vander Nat, P. J., 2014, p. 189.

11 Ibid., p. 189.

12 For example, the California Perfume Company, today known as 'AVON', was founded in 1886. In 1929, it already had a $\$ 2.5$ million revenue. Ibid. p. 190.

13 Keep, W. W., Vander Nat, P. J., 2014, p. 189.

14 See, e.g., Vincent G. E., 1973, Multi-Level or Pyramid Sales Systems: Fraud or Free Enterprise, South Dakota Law Review, Vol. 18, No. 2, Spring, pp. 358-393. 
onto the members themselves. MLM became attractive because it also offered a 'business opportunity', or a job-like position with potentially stable income what might develop into a quasi-independent business by "creating a downline of all direct or indirect recruits." ${ }^{15}$ A distinct vocabulary developed over time, too. ${ }^{16}$ The growth of the MLM industry in and after the 1970s, and subsequently also in the world, was spectacular. For example, while in the 1990s only $25 \%$ of the members of the US Direct Selling Association were MLMs, in 2011 that number increased to $96 \% .^{17}$

As opposed to the door-to-door salesman operating on 'one-level' and earning his income from commissions, MLM is based on a multi-tiered structure, where income from recruitment is as important as the one from sales. Another crucial difference is that members are entitled also to get a specific percentage from the earnings of all generations of 'downline' of members. Put simply, the more levels of recruits, (potentially) the more commissions/income. This also means that MLM, as a new method of marketing stands on two feet: the marketing (sales) and the continuous recruitment prongs. The income of a MLM venture therefore stems from sales revenues and from the contributions of ever newer members of the system. To survive, in other words, besides selling certain products or services, recruitment of new members is inevitable as well.

As a form of direct marketing, it is a form of disintermediated sales meaning that it is the seller - known under various designations from member, distributor, participant, representative, partners, associates, independent business owners to contractor ${ }^{18}$ - who directly approaches the potential purchasers with its offer and that there are no separate selling locations like shops, outlets, super- or hypermarkets. Or, as the US Federal Trade Commission phrased it in its warning to consumers: "MLM companies sell their products or services through person-to-person sales. That means you're selling directly to other people, maybe from your home, a customer's home, or online." 19

Particular attention is furthermore devoted in the recruitment process of MLMs to the manner in which the concrete recruitment steps need to be taken. These are not only elaborated to the greatest detail, but are to be performed uniformly. In one of the US cases from the 1970s concerning the then notorious Koscot scheme, ${ }^{20}$ this is described to include three stages: the solicitation of prospective members to the so-called 'Opportunity Meetings', conducting the meeting itself "in conformity with scripts prepared by Koscot", and as the last

15 Ibid., p. 192.

16 Ibid., p. 192. Keep \& Vander mention upline versus downline as well as personal versus group volume. Ibid.

17 Bosley, S., McKeage, K. K., 2015, Multi Level Marketing and the Risk of Pyramid Scheme Activity: the Case of Fortune Hi-Tech Marketing in Montana, Journal of Policy \& Marketing, Vol. 34 (1) Spring, pp. 84-102, at 85.

18 See, e.g., Keep, W. W., Vander Nat, P. J., 2014, p. 192.

19 FTC, Multi-Level Marketing Businesses and Pyramid Schemes at Multi-Level Marketing Businesses and Pyramid Schemes accessed 3 September 2020.

20 Securities and Exchange Commission v. Koscot Interplanetary, Inc. 497 F.2d 473 (US Court of Appeals, $5^{\text {th }}$ Cir., 1974). 
phase, consummation of the sale. The prescribed ritual, it is important to note, required Koscot employees participating at the Opportunity Meetings "to foster an illusion of affluence" by driving to the meeting in expensive cars, to dress expensively and "to flaunt large amounts of money." The intention was (as it is today) to make the prospective members sign the contracts on joining the system already at the meeting. ${ }^{21}$

From the point of view of regulators, the marketing aspects are the less problematic. It is the recruitment aspect of MLM that is the primary source of concerns for policy makers for more reasons. For seeing why is that so, and whether MLM as a form of direct marketing (sale) should be banned, or restricted, we need first to take a look at what pyramid schemes are and why are they such grave concerns for the law. What makes things complicated is that while pyramid schemes understood as forms of financial fraud are as a rule illegal, MLM schemes are not necessarily. At least, this is the case in the European Union (EU) and in the United States, and the jurisdictions that follow these approaches otherwise these all resting on very similar foundations.

\subsubsection{Pyramid Schemes Defined}

The first point to note is that pyramid schemes are peculiar forms of financial fraud, which as such should be forcefully reacted upon by regulators. The optimal solution would be prevention of their emergence yet that is hardly achievable, among others, because they can hide behind such legitimate business forms as MLMs. This is why in developed systems organization and promotion of pyramid schemes is criminalized though the regulatory as well as prosecutorial patterns differ. For example, while in Austria ${ }^{22}$ and Hungary ${ }^{23}$ a distinct, nominated crime specifically prohibiting promotion of pyramid schemes is enshrined into their criminal codes, in other countries general crimes are relied on by prosecutors. In case of the latter, besides the crime of 'fraud', the American specialty of 'mail fraud,' as well as money laundering could be mentioned. Developed systems, on top of the criminal enforcement system, employ also consumer protection law to combat the schemes. As we shall see in a bit more detail below, the US singularly employs all the tools of the federal securities regulatory system as well; something not characteristic to Europe, for instance.

Second, another corollary of pyramid schemes is that their organizers, the insider control-holders, typically start consuming up large portions of members' monetary contributions and income earned through sales activities, from day one. This is so because displaying their lavish life-style to the public, and thus to the potential new members, is an essential ingredient of the tactics of pyramid schemes; as it is of MLMs as well. Uninterrupted disbursement of the promised dividends, interest or other forms of remuneration, to earlier generation of members is a must as well, given that the stoppage, or any glitches with pay-

21 Ibid.

22 See $\$ 168$ a of the Austrian Penal Code 1974 (as amended in 2019) (“Strafgesetzbuch").

23 Section 412 of Act Number C of year 2012 on the Criminal Code ("2012. évi C. törvény a Büntető Törvénykönyvröl”). 
ments might frighten off new members. Yet these pay-outs eat up the capital of the schemes, too. Systematic and planned removal and hiding of scheme assets along the road to the abyss is also often resorted to by the insiders.

The third feature ensues from the above two: pyramid schemes inevitably collapse. They go bust because they exist only until sufficient number of new members can be recruited. Yet as the number of potential new members is mathematically limited, every pyramid is doomed to fall after the pool of potential new members dries up; if not earlier.

The collapse in countries with working bankruptcy systems leads then to opening of bankruptcy (insolvency) proceedings against the fallen schemes, which often reach to that stage with 'empty pockets' as the continuity of the system requires constant disbursements to earlier generations of members and for financing the lavish lifestyle of controlling-members, who are running and truly benefiting from the 'show' - as already hinted at above. If the bankruptcy system, especially avoidance laws, work efficiently and thus the profits that had been paid out before the collapse, either to the scheme-controllers, or the earlier generations of members, could be traced and returned into the bankruptcy estate, investors (and creditors: if any) could realistically expect some returns. Unfortunately, as the known examples suggest, this is more the exception rather than the rule. ${ }^{24}$ Yet where the bankruptcy system is defunct, it does not even make sense to file for opening of bankruptcy proceedings as due to the impotent bankruptcy avoidance laws it is fruitless to go after the moneys that had been removed from the books of the scheme.

From among the Serbian pyramid schemes, the case of the so-called 'Game Collection Club' (in Serbian: Gem Kolekšn Klub) stands out, which operated between 2004 and 2011. Allegedly about 27 million Euros disappeared in the system and more than five million Euros of taxes and social-security contributions have not been paid in the Serbian budget by it so far. More than twenty people, many attorneys, were prosecuted for tax dodging, money laundering and misuse of official position. ${ }^{25}$

Cases of fallen pyramid schemes of all sorts and dimensions can easily be found in the more recent history of Serbia's neighbors as well. Although these did not surface in the garbs of MLMs, they are suitable to show that pyramid schemes are hardly unknown in the region. Let us mention only the following three: the collapse of the Albanian shadow banks taking down the whole governmental system in 1996-97 and resulting in about 2,000 people being killed, ${ }^{26}$

24 The best available more recent example comes from the US: the 'Madoff Recovery Initiative.' As it can be seen from its webpage, $\$ 14,353$ billion was made available for recoveries \& settlements by $21^{\text {st }}$ August 2020. See at https://www.madofftrustee.com/ accessed on 6 September 2020. Although the Madoff scheme was a Ponzi scheme, the claims made here could be mutatis mutandis applied to pyramid schemes as well.

25 See V. M., Zbog organizovanja piramidalne prevare 24 uhapšenih, daily 'Novosti', issue as of $19^{\text {th }}$ June 2012, available electronically at https://www.novosti.rs/vesti/naslovna/hronika/ aktuelno.291.html:384893-Zbog-organizovanja-piramidalne-prevare-24-uhapsenih accessed 6 September 2020.

26 See Jarvis, C., 2000, The Rise and Fall of the Pyramid Schemes in Albania, IMF Staff Papers, Vol. 47, No. 1. 
the Romanian Caritas circulating about one to five billion US dollars and having between two to four million members in the years from 1992 to $1994,{ }^{27}$ and the four-teen Hungarian real-estate investment cooperatives in existence in 2003 and 2004 with about fifteen thousand consumer-investors, many pensioners. ${ }^{28}$ These ought to make the reader realize what the real dimensions of the problems this paper is focused upon are.

\subsubsection{Naked-versus Income-Producing Schemes}

The so-called 'naked pyramid schemes' present the worst case scenario. These are apostrophized as 'naked' because they pursue no income-generation economic activity whatsoever. Consequently, the chances of any recovered upon collapse are zero, or the bare minimum, in their case.

The situation is less drastic in case of pyramid schemes with some economic activity as some assets may remain available for distribution to former members and creditors, within and outside bankruptcy proceedings. While in case of naked pyramid schemes it goes without saying that they are fraudulent, in cases where the economic activities clearly and unequivocally dominate, the verdict on the nature of the venture obviously must be the opposite. As the US Federal Trade Commission put it: "[t]hey promise consumers or investors large profits based primarily on recruiting others to join their program, not based on profits from any real investment or real sale of goods to the public." ${ }^{29}$ [Emphasis added.] The logic of the US Amway and the EU '4Finance UAB' tests containing the formula for differentiating the 'good from the bad' schemes, to be presented in a bit more detail below, rests on these considerations and factors.

\subsubsection{A Word on Ponzi Schemes Obiter}

As a form of financial fraud, similarly to such new legal disciplines as capital markets and securities regulation, which both are still not conventional subjects covered by law school curricula in post-socialist systems, including the Western Balkans, a brief comment is needed on the expression 'Ponzi scheme', next of kin of pyramid schemes. Namely, the US nomenclature, properly reflecting the fact that US possesses one of the most developed and tested securities laws, differentiates between two kin forms of financial fraud: pyramid versus Ponzi schemes. Although they closely resemble, the Ponzi schemer is closer to a 'portfolio manager' to whom money (investment) is given because of a promise of above-the-average profits (returns), what is then - similarly to pyramid schemes

27 See, e.g., Smeureanu, M. I., Giurgea, F., Enforcement of Contracts in Romania, in: Messmann, S., Tajti, T. (eds.), 2009, The Case Law of Central and Eastern Europe - Enforcement of Contracts, Bochum-Germany, European University Press, note 1, p. 680.

28 See, e.g., Tajti, T., 2005, Central European Contribution to the American Debate on the Definition of 'Securities' or Why does the Definition of 'Security' Matter?: The Fiasco of the Hungarian Real Estate Investment Cooperatives, Pyramiding, and Why Emerging Capital Markets should be Equipped to 'Act' rather than 'React', Transnational Law \& Contemporary Problems, Vol. 15, No. 1, Fall, pp. 111-216.

29 See the related FTC explanation at https://www.ftc.gov/public-statements/1998/05/pyramidschemes accessed on 5 September 2020. 
- actually paid from the money brought in by the ever newer generations of investors. ${ }^{30}$ The formula of 'Rob Peter to Pay Paul' is common to both.

In Serbia, the 'Dafiment' and 'Jugoskandik' bank fiascos, well-known in the 1990s to many who have lost their investments, are the most notorious Ponzi schemes with the alleged involvement of the government back then. ${ }^{31}$ If, on other hand, the US is taken a look at as the country where the largest number of Ponzi schemes are prosecuted and reacted upon by the SEC, ${ }^{32}$ then undoubtedly it is the Madoff saga having emerged in the aftermath of the 2008 Credit Crunch and global financial crises that should be mentioned. What the COVID19 era will bring to the surface, we'll see soon. ${ }^{33}$

Yet as our article is focused on MLMs, apart from this brief comment, no further inquiry into the complex topic of Ponzi schemes is needed as MLMs are overwhelmingly discussed paired with pyramid schemes, as functionally and structurally more resembling players on the market. Still, it ought to be noted only that sometimes the expressions 'pyramid' versus 'Ponzi schemes' are used interchangeably, or incorrectly. Though the terminology of some non-English languages may as well blur the picture, as it is the case for example with Hungarian language, where the expression 'pyramid game' (piramisjáték) extends to both. Moreover, unlike Serbia where the expression 'Ponzi scheme' seems to gradually become used, at least, by authors of various internet sources, that has not been the case in Hungary so far, for example.

\section{THE REGULATORY RESPONES IN A NUTSHELL}

\subsection{MULTI-LEVEL MARKETING IN THE UNITED STATES}

Decades were needed, until a greater number of pyramid schemes disguised as MLMs have been detected in the US as systemic problems prompting for regulatory reactions at the beginning of the 1970 s. ${ }^{34}$ Ever since, this has remained the number one concern for US regulators as far as MLMs are concerned. What

30 See in particular the related explanatory pages of the US Securities and Exchange Commission (SEC) on Ponzi Schemes at https://www.sec.gov/fast-answers/answersponzihtm.html and on pyramid schemes at https://www.sec.gov/fast-answers/answerspyramidhtm.html as well as INVESTOPEDIA: Ponzi vs: Pyramid Scheme: An Overview at https://www.investopedia. com/ask/answers/09/ponzi-vs-pyramid.asp accessed 5 September 2020.

31 See Brkić, M., Kako je nastala i propala Dafiment banka: Pipci i konci svemoćnog gazde [The Emergence and Fall of the Dafiment Bank: All the Tentacles and Trumps of the Allmighty Boss], in: Vreme 536 (12 Apr. 2001), at https://www.vreme.com/cms/view.php?id=96130 accessed 5 September 2020. See also Turanjanin, V., Privredna krivična dela iz sporednog krivičnog zakonodavstva, in: Stevanović, I., Čolović, V. (eds.), 2017, Privredna krivična dela, Institut za uporedno pravo, Institut za kriminološka i sociološka istraživanja, Belgrade, pp. $203-215$, at 112.

32 For a list of detected US Ponzi schemes from the last few years see the website PONZITRACKER, run Jordan Maglich, Florida attorney at https://www.ponzitracker.com/about accessed 5 September 2020.

33 Bartalos, G., 2020, Madoff is behind Bard. But with Markets Infected by Covid-19, More Ponzi Schemes may be Unmasked, RIAINTEL, 7 April.

34 Keep, W. W., Vander Nat, P. J., 2014, History of MLM, p. 194. 
makes US peculiar is that it is not only the FTC but also the Securities and Exchange Commission (SEC) that is combating pyramids camouflaged as MLMs. In fact, as some authors claim "[t]he MLM Model facilitated the growth of pyramid scheme fraud, creating victims rather than customers." 35

After a few successful prosecutions, the 1970s produced the two most important decisions still forming the backbone of the regulatory system: the 1979 Amway Test ${ }^{36}$ born out of a tug-of-war between FTC and Amway - one of the top US MLM corporations created in $1959^{37}$ - and the Koscot case adjudicated based on securities laws (otherwise briefly mentioned already above). The two prongs, the antitrust-cum-consumer protection versus the securities prong, have been thereafter relied on by consumer-claimants separately save a few double-track cases. In the 1996 Omnitrition case, for example, the distributors sued the company specialized in health and skin-care products for their losses claiming that the MLM was a pyramid schemes, and the primarily line of attack was based on securities laws but with invoking also the Amway test. ${ }^{38}$

For understanding the Amway test, one has to bear in mind that it was a result of a compromise as part of which the FTC accepted as a proof of the dominance of the non-recruitment aspects of Amway's tiered system that Amway's policies "required participants to buy back any unsold inventory from their recruits [and] each participant was required to sell at wholesale or retail at least 70 percent of the products in a given month to at least 10 different consumers in order to receive a bonus." 39 The internal policies of Amway, in other words, forced the members to produce palpable sales results each month to receive the bonuses in addition to recruiting new members. As the related policies of other MLM systems differ, the Amway test presumes a case-by-case analysis to figure out whether the test was satisfied.

The tests applied by FTC and SEC, however, understandably have not wiped out pyramid schemes completely from the market and thus the struggle continues. For example, in a pretty recent case involving an MLM scheme hardly known outside the US - the Montana-based Fortune Hi-Tech Marketing venture - after being sued by six states and the FTC, the firm was closed down for good on test-based grounds in $2014 .^{40}$

35 Ibid., p. 194.

36 Matter of Amway Corp., Inc., 93 F.T.C. 618 (1979).

37 AMWAY, or the American Way Association was formed by two distributors leaving Nutrilite dissatisfied with the uncertainties caused by Nutrilite's dispute with the US Food and Drug Administration in 1959. Amway eventually took over control over Nutrilite in 1994, which was founded in 1934 by Carl. F. Rehnborg for marketing minerals, vitamins and dietary supplements. See the website of Amway at https://www.amway.com/en_US/nutrilite accessed 4 September 2020.

38 Webster v. Omnitrition International Inc. 79 F.3d $776\left(9^{\text {th }}\right.$ Cir. 1996). For the discussion on the Amway test see Section C at pages 782-83.

39 Barkacs, B. C., Multilevel Marketing and Antifraud Statutes: Legal Enterprises or Pyramid Schemes? Journal of the Academy of Marketing Science, Vol. 25, No. 2, pp. 176-179, at 177.

40 See Bosley, S., McKeage, K. K., 2015, Multi Level Marketing and the Risk of Pyramid Scheme Activity: the Case of Fortune Hi-Tech Marketing in Montana, Journal of Policy \& Marketing, Vol. 34 (1), Spring, pp. 84-102. 
The Amway test survived up until today though as refined through subsequent agency and court cases. One of them, the 2014 BurnLounge case ${ }^{41}$ involved, for example, an interesting sales \& recruitment formula. According to it the participants had to purchase a 'package' from the MLM for a yearly subscription fee that then entitled them to market not only the business' music and other merchandize but also the 'packages'. The Appellate court affirmed the district court's holding "that BurnLounge was an illegal pyramid scheme, in violation of $\S 5(\mathrm{a})$ of the FTCA." 42

If the involvement of the SEC, and securities regulations, is something hard to conceive, one should not forget that the initial and subsequent monetary contributions paid into an MLM by consumer-members makes them investors as well; more precisely consumer-investors that the wide-reaching US federal securities regulatory system is expected to protect as well. The tool whereby this occurs is the so-called 'economic' (or functional) definition of 'security' enshrined into the key federal acts still forming the core of the system. These acts are the 1933 Securities Act regulating the primary, and the 1934 Securities Exchange Act that tackles issues emerging on the secondary markets. ${ }^{43}$

This definition is said to be 'economic' because it works on the basis of the internal structure of investment schemes and not on the labels under which they are offered. In practical terms this means that if the features of a new, or unorthodox investment scheme, resemble paradigm securities (i.e., shares, bonds), they will be treated identically, no matter the naming. To note: these have been developed not only for MLMs, pyramid and Ponzi schemes but they apply generally and catch other types of unorthodox investments as well.

Courts developed two tests, the 'Howey-test' ${ }^{44}$ for equity-type and the 'Reves test ${ }^{45}$ for fixed-income-type 'investment schemes.' These remain the basic tools for determining whether an offering is caught by the securities regulations; and if it is, all the protections known by the system apply, from the duty of registration and disclosure to SEC investigations coupled with the possibilities of imposing cease-and-desist orders and other ancillary measures. This is one of the most complex areas of US law, only partially paralleled in Europe. Hence, for our purposes the above should be sufficient to realize that for the US system pyramid and Ponzi schemes, including MLMs, rank high on the regulatory agendas, moreover of more agencies.

The quest for an even simpler formula based on which illegal pyramid schemes could be differentiated from legitimate MLMs in the US continues,

41 F.T.C. v. BurnLounge, Inc. 753 F.3d 878 ( $9^{\text {th }}$ Cir. 2014).

42 Ibid., conclusion.

43 In simple terms, the 'primary market' means the issues, questions corollary to putting a security for the first time on the market, or what is known as initial-public offerings (IPOs). As opposed to that, the expression 'secondary market' concerns questions that occur in the life of securities that are already traded on the markets.

44 The test was formulated by the US Supreme Court in the 1946 case SEC v. W.J. Howey Co. 328 U.S. 293, 66 S.CT. 1100, 90. Ed. 1244.

45 The test was forged by the US Supreme Court in the 1990 case Reves v. Ernst \& Young 494 U.S. 56, 110 S.Ct. 945, 108 L.Ed.2d 47. 
as best shown by the Blackburn-Veasey bill submitted to the US federal Congress in 2018. ${ }^{46}$ The bill's goal was "to bring clarity and consistency [for] distinguish[ing] illegal pyramids from legitimate MLMs." ${ }^{\prime 7}$ What the fate of the bill will be, remains to be seen.

\subsection{MULTI-LEVEL MARKETING IN THE EUROPEAN UNION}

Uttering two catchwords suffices to canvass the contours of EU law on MLMs: the 2005 Unfair Commercial Practices Directive ${ }^{48}$ and the European Court of Justice's '4finance UAB' decision. ${ }^{49}$ Point 14 of Annex I of the former proclaims that "establishing, operating or promoting a pyramid promotional scheme" qualifies as a misleading commercial practice that is 'considered as unfair in all circumstances.' The second half of the sentence in point 14 then already adds the essence of the '4Finance UAB' judgment in very similar terms to the US Amway test, linking the illegality of a tiered marketing scheme to the dominance of recruitment aspects..$^{50}$ Or, as the ECJ formulated, "a pyramid promotional scheme constitutes an unfair commercial practice only where such a scheme requires the consumer to give financial consideration, regardless of its amount, for the opportunity to receive compensation that is derived primarily from the introduction of other consumers into the scheme rather than from the sale or consumption of products." 51

As far as the cases on MLMs and pyramid schemes are concerned, most surfaced at the level of the Member States and very few has reached the dockets of the European Court in Luxembourg. ${ }^{52}$ The related scholarship is not rich either. ${ }^{53} \mathrm{Al}-$ though the Babylonian Chaos makes research hard as many of the local language

46 Bill H.R. 3409.

47 Sobieraj, R. J., 2018, Myth about Self-Consumption in MLMs, National Law Review, 22 February.

48 Directive 2005/29/EC of the European Parliament and of the Council of 11 May 2005 concerning unfair business-to-consumer commercial practices in the internal market and amending Council Directive 84/450/EEC, Directives 97/7/EC, 98/27/EC and 2002/65/EC of the European Parliament and of the Council and Regulation (EC) No 2006/2004 of the European Parliament and of the Council ('Unfair Commercial Practices Directive'), L 149/22.

49 '4finance' UAB ECLI:EU:2014:211, preliminary ruling as of 3 April 2014. Hereinafter: '4finance' UAB ruling or case.

50 The relevant part reads: "where a consumer gives consideration for the opportunity to receive compensation that is derived primarily from the introduction of other consumers into the scheme rather than from the sale or consumption of products."

51 '4finance' UAB judgment para 35.

52 See for example the database on unfair commercial practices, established in 2001 and then moved to the e-Justice portal on 31 October 2018. It is now available at https://e-justice.europa.eu/resultManagement.do?stext=Unfair+commercial+practices+database\&amp;itext $=$ Unf air+commercial+practices + database\&amp;sco=any\&amp;slang=any\&amp;sctype $=$ content $T y$ peAny\&amp;spage $=25 \& a m p ;$ slmo $=$ anytime \&amp;soption $=c, n, a, \& a m p ;$ showPage $=1 \&$ amp; $\mathrm{val}=8260 \mathrm{cb} 397 \mathrm{c} 3 \mathrm{bb} 98 \mathrm{f} 01 \mathrm{bf} 75 \mathrm{f} 83 \mathrm{~b} 8 \mathrm{c} 65 \mathrm{bf} \# \mathrm{fco}=1 \& \mathrm{fctype}=$ contentTypeCld accessed 5 Septem ber 2020 .

53 See, e.g., Stuyck, J., 2015, The Court of Justice and the Unfair Commercial Practices Directive, Common Market Law Review, 52, pp. 721-752. 
decisions never get to be translated and thus it is next to impossible to assess how many cases have been adjudicated related to MLMs or pyramid schemes, even a look at a few could reveal a lot not only about the frequency and thus socio-economic relevance of these but also on the garden-variety of their contents.

As the Hungarian economic and legal environment is quite similar to those of Serbia, a few examples based on the cases decided upon by the Hungarian Competition Authority or Hungarian courts might be telling. These could appropriately cast a light on how unusual some MLM practices could be and how the concept is perceived among businessmen; not necessarily fitting the picture one gets having such brand names as AVON or AMWAY as benchmark.

In a 2012 civil case reaching the Hungarian Supreme Court (the Curia), ${ }^{54}$ damages were asked by the plaintiff - formerly holding the position of a 'diamond director' in the tiered structure of the defendant - for inappropriate termination of a 'beauty-advisory service contract', the contract whereby the plaintiff had joined the MLM. It is not fully clear from the published text of the case, yet the claimant alluded that such an MLM was at stake, which provided the members with a "projectable continuous remuneration," and which should have been taken into account by the court when awarding the damages suffered by the unjustified termination of the said contract. Moreover, as the plaintiff put forward, the clients' list compiled by the plaintiff as part of its recruitment and sales efforts also had an assessable monetary value, which was another factor disregarded by the court when fixing the amount of damages. The Curia, otherwise, found that the mentioned underlying contract (without expressly stating that an MLM was at stake) to be an atypical contract invoking the application of the general provisions of the Hungarian Civil Code of 2013. ${ }^{55}$

Even more telling is the 2014 decision of the Hungarian Competition Authority, ${ }^{56}$ detailing the features of an MLM that was the product of cooperation between two properly established insurance companies (CIG Pannónia Életbiztosító Nyrt, public corporation and Reál-Team Network Kft, or Ltd.), focused on life-insurance products. As the Authority determined, described in great detail in a 41 pdf pages long decision, the life insurance products were marketed through a pyramidal, tiered structure, in which the members were rewarded for their recruitment efforts not only by commissions but also by becoming insureds at the same time. Put simply, the members of the system were such insurance brokers who recruited new insurance brokers yet becoming insureds as well upon fulfillment of the set tresholds. As one could assume based on the '4finance' UAB test, that had been duly transposed to the Hungarian legal system by then, the practice was declared unfair commercial practice because based on the underlying contracts "the consumer [the insurance-broker members of the system] did reckon

54 Kúria Gfv. 30108/2012/8.

55 Act No. V. of year 2013 on the Civil Code (2013. évi V. törvény a Polgári Törvénykönyvröl); as amended.

$56 \mathrm{Vj} / 102 / 2013$ (as of $19^{\text {th }}$ of December 2014). Decision available in Hungarian language at the website of the Hungarian Competition Authority at https://www.gvh.hu/pfile/ file?path=/dontesek/versenyhivatali_dontesek/versenyhivatali_dontesek/dontesek_2013/ Vj102_2013_m\&inline=true accessed 5 September 2020. 
with some remuneration yet less from the sale or consumption of products and rather from the recruitment of new members to the system." It is particularly interesting detail in the related business strategy of the organizer-companies that they have tried primarily to recruit unemployed people, because "they can be more easily motivated." ${ }^{57}$ An astronomic fine of 22,640,000 million Hungarian Forints was imposed on the insurance companies by the Authority.

Lastly, there are already as well criminal cases ${ }^{58}$ in which the courts have correctly noted that MLMs are not per se fraudulent yet have found that behind the tiered structure actually a pyramid scheme was lurking on innocent victims. As the Hungarian Supreme Court put it, the guilt of the culprit stems from the fact that "the accused knew that the system will not produce any income save the entry-fees collected from the members," irrespective of what "he bilked money out of them without intending to perform his promises."

\section{THE DARK SIDE OF THE COIN}

Notwithstanding the trend of subjecting MLMs to regulations, open questions remain. Apart from the regulatory capture allowing the MLM mammoths, especially in the US and Western Europe, to impact the contents of the regulations applicable to them thanks to their financial strength and the resulting lobbying power, it is a major issue that often MLM members, save those belonging to the closed top circle, do not make any income from participating in the system. Unfortunately, quantitative data are typically available only in the US and therefore one can hardly find comparable information related to such new host jurisdictions of MLM ventures as Serbia or the broader region. But the information stemming from the US could properly illustrate the dimensions of the problem. As Keep and Vander noted related to the 2013 data of two MLM giants, 'Herbalife' and 'NuSkin,' "[t]he vast majority of distributors ... received no company compensation." ${ }^{59}$ Exceptions though exist, especially if proper regulations are in place and the enforcement agencies are adequately staffed with experts. The Texan AdvoCare International may be such an exception, in which thanks to the settlement with FTC all the unsold products had to be repurchased from members wanting to leave the system. ${ }^{60}$

Even more telling recent material is John Oliver's $7^{\text {th }}$ of November 2016 episode of his world-famous HBO talk show 'Last Week Tonight with John Oliver'61 devoted to the vices of MLMs, simply explaining and illustrating what the industry is about, how it works and what things may go wrong. As the members of

57 Ibid., para 24.

58 Kúria 1321/2018/6.

59 Keep, W. W., Vander Nat, P. J., 2014, p. 193.

60 Seena Gressin (attorney of the FTC Division of Consumer and Business Education), FTC: AdvoCare business model was pyramid scheme (2 Oct. 2019), at: https://www.consumer.ftc.gov/ blog/2019/10/ftc-advocare-business-model-was-pyramid-scheme accessed 5 September 2020.

61 The episode is available through Youtube at https://www.youtube.com/watch? $\mathrm{v}=\mathrm{s} 6 \mathrm{Mw}$ GeOm8iI accessed 4 September 2020. 
MLM systems are almost exclusively individuals, consumer-investors, normally not a dozen but hundreds if not thousands are impacted. It is not only that they may not make often any income, but equally bad is that frequently they cannot withdraw their investments either even though the system is solvent and thus would be in the position to pay. In other words, based on internal policies of the schemes, the members' investments could remain blocked within the system for unlimited period of time.

In many African, Asian or Latin American countries MLMs have also become popular and regrettably some have turned out to be nothing else by pyramid schemes. Yet as the socio-economic environment amidst of which these emerge is radically different from those in EU countries, the nature, severity and the dimensions of corollary problems do not match those known in the western hemisphere either. Especially as the safety cushions existent in most EU countries in the form of generous social-security systems, high welfare standards and availability of individual savings that could soften the negative consequences of losses in fallen schemes, often are lacking in fledgling economies. Further, in emerging systems often the number of unbanked people that join MLMs counts in thousands, as they see MLMs as offering job-like positions with stable income. Though admittedly often simple greed and gullibility plays the key role in deciding to join. Yet where thousands of consumers lose often their families' life-savings, systemic risks endangering financial and social stability may emerge, especially if an MLM turns out to be a pyramid scheme and collapses.

The immature nature of the financial and legal system, lack of experience and unpreparedness to deal with such novel and sophisticated phenomena as MLMs and pyramid schemes may then prevent the successful borrowing of such tests as the US Amway or the EU '4finance UAB' for distinguishing the two. For example, Sri Lanka ${ }^{62}$ has simple banned all kinds of MLMs recently instead of taking over these tests. Myanmar (former Burma), ${ }^{63}$ which stepped onto the path towards democracy and market economy after the fall of the earlier military regime in 2011, understandably had to do the same ${ }^{64}$ as the Myanmar lawmakers realized that their judges and the staff of agencies that should deal with MLMs and pyramid schemes lack the knowledge and experience to properly deal with the related problems known in the US and Europe. ${ }^{65}$

These problems come on top of more traditional ones that may also cause disruptions in the cash-flow of MLMs and have long been known in the US,

622005 Anti-Pyramid Act is accessible via the website of the US organization Pyramid Scheme Alert webpage at https://www.pyramidschemealert.org/PSAMain/news/SriLankaNewLaw. pdf accessed 5 September 2020.

63 Mai, N. K., 2019, 'Analytical Study on the Legality of Multi-Level Marketing', Journal of the Myanmar Academy of Arts and Science, XVII, No. 8, pp. 191-204.

64 See the Notification of the Ministry of Commerce No. 46/2018 on MLM Schemes (18 September 2018).

65 For a more detailed elaboration see Tajti, T., Are Some Classes of Consumer-Investors of Collapsed Pyramid and Ponzi Schemes Vulnerable? - A Multi-Jurisdictional Perspective - in: Stănescu, G. C., Gikay, A. A. (eds.), 2021, Discrimination, Vulnerable Consumers and Financial Inclusion: Fair Access to Financial Services and the Law, Routledge. 
like MLM practices going against antitrust (competition) law rules on exclusive dealing or non-compete sections of distributor contracts. ${ }^{66}$ These notwithstanding, one should not forget that not all MLMs are disguised pyramid schemes, or ventures that are known only for consumer-members losing.

\section{CONCLUSIONS}

One option for Serbia, and for other countries knocking on the doors of the European Union, is to tackle the problems potentially created by MLMs, especially by pyramid schemes disguised as MLMs, without procrastination. The respective parts of the acquis communautaire, namely, could easily be taken over already now. It should, however, not be forgotten that the responses of the EU are limited, a fact that becomes especially visible once EU law is compared to the experiences of others, especially the US undoubtedly possessing the richest toolbox of legal remedies exploitable to combat pyramid schemes and a panoply of related cases and experiences as well. As the US Amway and the European '4Finance' tests playing a key role in protecting the consumers and the integrity of the markets rest on similar foundations, the transposition of European lawcum-study of US experiences would be the most rewarding path to step on.

A regulatory reaction being limited to mechanical transposition of European law bears the risks that stem from the fact that it is still not known when will the transplantation occur, or more precisely, when will its real life implementation begin. Moreover, this article's seemingly narrow topic might be overshadowed and marginalized by the macro-economic and politically more important aspects of EU law to be taken over, too. In other words, postponing the regulatory reactions, or presuming that EU law will solve everything, is not the suit to be followed by these countries as until things turn to the better hundreds of consumers may fall victim of the schemes.

A responsible government that wants to care for the collective rights of consumers would rather take action, learn from the experiences of others, and make the needed sector-specific regulations not waiting until a major collapse involving hundreds of victims generates a political issue out of it. It would be also imperative to entrust a governmental agency with collection and analysis of pertaining empirical data to see things more clearly. Educational campaigns are obviously a must as well, ${ }^{67}$ though posting pages warning consumers about

66 At issue were section 3 of the 1914 Clayton Act and section 5 of the 1914 Federal Trade Commission Act. See the case Mytinger \& Casselberry, Inc. v. FTC (1962), 301 F. 2d 534, Court of Appeals, Dist. of Columbia Circuit on non-competition clauses, cited by Keep, W. W., Vander Nat, P. J., 2014, p. 193.

67 The conclusion of Turanjanin related to most famous Serbian Ponzi schemes, Dafiment Bank and Jugoskandik, suits the context of MLM schemes as well: "Had [Serbian] citizens known whad had happened 70 years ago [in the US with Charles Ponzi's investment scheme], and had somebody from the many analysts and journals told the story of the fraudster Mr. Ponzi to the citizens, clear and loud, to the citizens, the saga of Dafina and Jugoskandic would have presumably ended differently." (In Serbian, "Da su građani znali šta se dogodilo skoro 70 godina pre toga, kao i da je neko od analitičara i novinara građanima, jasno i glasno ispričao priču o 
the possibilities that a pyramid scheme might be lurking behind the MLM label would obviously be needed but would also be insufficient. Giving a thought to how the above should be reflected in the curricula of law schools would be wise as well. Yet the ultimate caveat one should not forget about when thinking about these practical matters is that irrespective whether one is for or against MLMs, undoubtedly neglect and ignorance of the topic is the worst possible answer to all the related dilemmas. ${ }^{68}$

\section{BIBLIOGRAPHY}

1. Barkacs, B. C., Multilevel Marketing and Antifraud Statutes: Legal Enterprises or Pyramid Schemes? Journal of the Academy of Marketing Science, Vol. 25, No. 2.

2. Bartalos, G., 2020, Madoff is behind Bard. But with Markets Infected by Covid-19, More Ponzi Schemes may be Unmasked, RIAINTEL, 7 April.

3. Bosley, S., McKeage, K. K., 2015, Multi Level Marketing and the Risk of Pyramid Scheme Activity: the Case of Fortune Hi-Tech Marketing in Montana, Journal of Policy \& Marketing, Vol. 34 (1) Spring.

4. Friedman, W. A., 2004, Birth of a Salesman: The Transformation of Selling in America, Cambridge, MA, Harvard University Press.

5. Keep, W. W., Vander Nat, P. J., 2014, Multilevel Marketing and Pyramid Schemes in the United States: An Historical Analysis, Journal of Historical Research in Marketing, 6.

6. Mai, N. K., 2019, Analytical Study on the Legality of Multi-Level Marketing, Journal of the Myanmar Academy of Arts and Science, XVII, No. 8.

7. Smeureanu, M. I., Giurgea, F., Enforcement of Contracts in Romania, note 1, at 680, in: Messmann, S., Tajti, T. (eds.), 2009 The Case Law of Central and Eastern Europe Enforcement of Contracts, Bochum-Germany, European University Press.

8. Sobieraj, R. J., 2018, Myth about Self-Consumption in MLMs, The National Law Review, 22 February.

9. Stuyck, J., 2015, The Court of Justice and the Unfair Commercial Practices Directive, Common Market Law Review, 52.

10. Tajti, T., Are Some Classes of Consumer-Investors of Collapsed Pyramid and Ponzi Schemes Vulnerable? - A Multi-Jurisdictional Perspective - in: Stănescu, G. C., Gikay, A. A. (eds.), 2021, Discrimination, Vulnerable Consumers and Financial Inclusion: Fair Access to Financial Services and the Law, Routledge.

11. Tajti, T., 2005, Central European Contribution to the American Debate on the Definition of 'Securities' or Why does the Definition of 'Security' Matter?: The Fiasco of the Hungarian Real Estate Investment Cooperatives, Pyramiding, and Why Emerging

prevarantu Ponziju, stvar sa Dafinom i „Jugoskandikom“ bi možda bila drugačija.") See Turanjanin, V., Privredna krivična dela iz sporednog krivičnog zakonodavstva, in: Stevanović, I., Čolović, V. (eds.), 2017, Privredna krivična dela, Institut za uporedno pravo, Institut za kriminološka i sociološka istraživanja, Belgrade, pp. 203-215, at 112.

68 That the neglect of pyramid and Ponzi schemes, including those masked as MLMs, by regulators may have serious consequences on the economy and especially consumers was the central message also of my article Tajti, T., 2019, Pyramid and Ponzi Schemes and the Price of Inadequate Regulatory Responses: A Comparative Account of the Diverging Regulatory Responses of China, Europe, and the United States, Bus \& Bankruptcy Law Journal, 5, p. 19. 
Capital Markets should be Equipped to 'Act' rather than 'React', TheTransnational Law \& Contemporary Problems, Vol. 15, No. 1, Fall.

12. Tajti, T., 2019, Pyramid and Ponzi Schemes and the Price of Inadequate Regulatory Responses: A Comparative Account of the Diverging Regulatory Responses of China, Europe, and the United States, Bus \& Bankruptcy Law Journal, 5.

13. Turanjanin, V., Privredna krivična dela iz sporednog krivičnog zakonodavstva, in: Stevanović, I., Čolović, V., (eds.), 2017, Privredna krivična dela, Institut za uporedno pravo, Institut za kriminološka i sociološka istrživanja, Belgrade, pp. 203-215, at 112.

14. Varga, S., Pravni aspekti mrežnog marketinga i zabrana piramidalne trgovine, in: Mićović, M. (ed.), 2014, XXI vek - vek usluga i uslužnog prava, Kragujevac, Pravni fakultet.

15. Vincent G. E., 1973, Multi-Level or Pyramid Sales Systems: Fraud or Free Enterprise, South Dakota Law Review, Vol. 18, No. 2, Spring.

\section{LEGISLATION AND SUB-STATUTORY SOURCES OF LAW}

\section{Austria}

1. Austrian Penal Code 1974 (as amended in 2019) ("Strafgesetzbuch").

\section{European Union}

1. Council Directive of 20 December 1985 to protect the consumer in respect of contracts negotiated away from business premises ( $85 / 577 / \mathrm{EEC})$.

2. Directive 2005/29/EC of the European Parliament and of the Council of 11 May 2005 concerning unfair business-to-consumer commercial practices in the internal market and amending Council Directive 84/450/EEC, Directives 97/7/EC, 98/27/EC and 2002/65/EC of the European Parliament and of the Council and Regulation (EC) No 2006/2004 of the European Parliament and of the Council ('Unfair Commercial Practices Directive').

\section{Hungary}

1. Hungarian Criminal Code [2012. évi C. törvény a Büntető Törvénykönyvről].

2. Act No. V. of year 2013 on the Civil Code (2013. évi V. törvény a Polgári Törvénykönyvről); as amended.

\section{Myanmar (former Burma)}

1. Notification of the Ministry of Commerce No. 46/2018 on MLM Schemes (18 September 2018).

\section{Sri Lanka}

1. 2005 Anti-Pyramid Act is accessible via the website of the US organization Pyramid Scheme Alert webpage at https://www.pyramidschemealert.org/PSAMain/news/SriLankaNewLaw.pdf 


\section{United States (federal level)}

1. Federal Trade Commission Act of 1914 (15 U.S.C. $\$ \$ 45-58$, as amended).

2. Securities Act of 1933 (15 U.S.C. $\$ 77$ a et seq.)

3. Securities Exchange Act of 1934 (15 U.S.C. $\$ 78$ a et seq.)

\section{CASE LAW}

\section{Hungary}

1. Kúria Gfv. 30108/2012/8 [Supreme Court Judgment in a civil case].

2. $\mathrm{Vj} / 102 / 2013$ (as of $19^{\text {th }}$ of December 2014) [Competition Authority decision].

3. Kúria 1321/2018/6 [Supreme Court Judgment in a criminal case.]

\section{United States}

1. F.T.C. v. BurnLounge, Inc. 753 F.3d 878 ( $9^{\text {th }}$ Cir. 2014).

2. Matter of Amway Corp., Inc., 93 F.T.C. 618 (1979).

3. Mytinger \& Casselberry, Inc. v. FTC (1962), 301 F. 2d 534, Court of Appeals, Dist. of Columbia Circuit.

4. SEC v. W.J. Howey Co. 328 U.S. 293, 66 S.CT. 1100, 90.Ed. 1244.

5. Reves v. Ernst \& Young 494 U.S. 56, 110 S.Ct. 945, 108 L.Ed.2d 47.

6. Securities and Exchange Commission v. Koscot Interplanetary, Inc. 497 F.2d 473 (US Court of Appeals, $5^{\text {th }}$ Cir., 1974).

7. Webster v. Omnitrition International Inc. 79 F.3d 776 ( $9^{\text {th }}$ Cir. 1996).

\section{INTERNET SOURCES}

1. Amway website, (https://www.amway.com/en_US/nutrilite).

2. Brkić, M., 2001, Kako je nastala i propala Dafiment banka: Pipci i konci svemoćnog gazde [The Emergence and Fall of the Dafiment Bank: Al the Tentacles and Trumps of the Allmighty Boss], in: Vreme 536, 12 April, (https://www.vreme.com/cms/view. php?id=96130).

3. E-Justice portal (of the European Union) with a database on unfair commercial practices, (https://e-justice.europa.eu/resultManagement.do?stext=Unfair+commercial+ practices+database \&amp;itext $=U$ nfair + commercial+practices + database $\& a m p ; s c o=a$ ny\&amp;slang $=$ any\&amp;sctype $=$ content TypeAny\&amp;spage $=25 \& a m p ; s l m o=$ anyti me\&amp;soption=c,n,a,\&amp;showPage =1 \&amp;hval=8260 cb397c3bb98f01bf75f83 b8c65bf\#fco $=1 \& f$ ctype $=$ content TypeCld).

4. Kompanije mrežnog marketinga koje posluju u Srbiji, (https://mlminternetposao. wordpress.com/2018/03/24/kompanije-mreznog-marketinga-koje-posluju-u-srbiji/).

5. Lyoness headquarters, (https://www.lyoness-corporate.com/en/).

6. 'Madoff Recovery Initiative', (https://www.madofftrustee.com/).

7. Multilevel Marketing: Last Week Tonight with John Oliver (HBO) (2016. Nov. 7), (https://www.youtube.com/watch?v=s6MwGeOm8iI).

8. Nagrale, Pritam, 40 Top MLM Companies in the World, (https://moneyconnexion. $\mathrm{com} / \mathrm{mlm}$-companies-in-the-world.htm). 
9. Pavlović, I., Multilevel marketing, kad se podvuče crta, in daily 'Politika', 22 October 2016 (http://www.politika.rs/sr/clanak/366121/Pogledi/Multilevel-marketing-kadse-podvuce-crta).

10. PONZI-TRACKER, Florida, (https://www.ponzitracker.com/about).

11. Seena Gressin (attorney of the FTC Division of Consumer and Business Education), FTC: AdvoCare business model was a pyramid scheme (2 Oct. 2019), (https://www. consumer.ftc.gov/blog/2019/10/ftc-advocare-business-model-was-pyramid-scheme).

12. V. M., Zbog organizovanja piramidalne prevare 24 uhapšenih, daily 'Novosti', issue as of $19^{\text {th }}$ June 2012, (https://www.novosti.rs/vesti/naslovna/hronika/aktuelno.291. html:384893-Zbog-organizovanja-piramidalne-prevare-24-uhapsenih).

\title{
OTHER
}

1. Jarvis, C., 2000, The Rise and Fall of the Pyramid Schemes in Albania, IMF Staff Papers, Vol. 47, No. 1.

\section{MREŽNI MARKETING I PIRAMIDALNE ŠEME}

\author{
Tibor Tajti
}

\section{REZIME}

Mrežni marketing (engl. Multi-level Marketing ili MLM), kao oblik direktne prodaje iz koje je i izrastao tokom 20. veka u SAD, danas je već industrija vredna više milijardi dolara. Pored američkih korporacija koje dominiraju u svetu i od kojih su se mnoge (npr. AMWAY, AVON, Herbalife) već pojavile, ne samo na tržištima zapadnoevropskih i drugih ekonomski razvijenih zemalja, nego i u siromašnijima, sve više ima i MLM kompanija iz drugih država kao što je austrijsko-švajcarska firma LYONESS i mnoge druge nepoznate u Srbiji i u regionu. I pored toga što su neke već prisutne i u Srbiji i na teritoriji bivše Jugoslavije, a još više u onim postsocijalističkim zemljama koje su u međuvremenu postale članice Evropske unije i zahvaljujući tome još šire otvorile svoja vrata stranim investicijama, regionalna pravna literatura je oskudna, a poslovni ljudi i naročito potrošači malo znaju o MLM-u.

Doduše u Srbiji je možda veći problem to što još nema formulisane pravne politike o MLM-u, što bi bilo poželjno ne samo zbog odbrane kolektivnih prava potrošača kao članova mrežnih sistema, nego i zbog potencijalnih negativnih makroekonomskih posledica koje kolaps nekog od sistema može prouzrokovati.

Inače bit mrežnih sistema, njihove glavne odlike i propratni rizici su dobro identifikovani u publikacijama koje se u Srbiji prvenstveno mogu pronaći u obliku univerzitetskih teza, internet publikacija MLM firmi i njihovih asocijacija i blogova - ne samo podržavalaca nego i kritičara mrežnih sistema. Mrežni sistemi se zovu tako jer se baziraju na piramidalnoj strukturi pripadnika sistema i gde se uski krug inicijatora, imajući u rukama kontrolu nad mrežom, nalazi na samom vrhu tog sistema i najčešće članovi koji jedino uistinski i profitiraju od sistema. Od svakog člana (a mogu imati razne nazive - od člana, participanta do distributera) očekuju se dve krucijalne stvari: kontinuirano regrutovanje novih članova i plasiranje robe ili usluga sistema (ako toga ima). Isti su i izvori prihoda mrežnih kompanija. Naravno, konkretni metodi kako se sve ovo odvija variraju. Na 
primer, kod nekih, za učlanjenje preduslov je neka početna uplata, dok se kod drugih to sastoji od obavezne kupovine početnog paketa proizvoda. Često se samo regrutovanje odvija po u detalje propisanom ritualu.

Dva bitna razloga objašnjavaju zašto se tematika mrežnih i piramidalnih sistema ne može odvojeno posmatrati, a obe se svode na zaštitu prava potrošača od ilegalnih piramidalnih šema. Prvo, u najvećem broju pravnih sistema, piramidalne šeme su poimane kao per se oblici prevare (fraus), jer se oni po pravilu i ne bave nikakvim privrednim aktivnostima koje bi donosile prihod i tako nužno bankrotiraju posle nekog kraćeg vremena. Opstaju dok ima priliva novih članova koji su voljni da uplate novčane doprinose jer starije generacije članova sistema se isplaćuju od priloga novoučlanjenih. Matematički se može iskazati da takvi sistemi moraju da imaju svoj kraj jer je broj potencijalnih novih članova limitiran. Kako organizatori istih znaju to, po pravilu deo novca se izmešta van sistema već od samog početka, tako da ukoliko stečajni postupak uopšte bude pokrenut protiv bankrotirane kompanije, neće biti imovine iz koje bi članovima (i poveriocima) moglo biti bar delimično nadoknađeno.

Drugi razlog zbog kojeg bi trebalo da zakonodavci reaguju jeste taj da su često piramidalni sistemi skriveni iza trgovačke marke, spoljašnje pravne fasade kompanije mrežnog sistema. U SAD, sam fenomen i rizici koji prate kamuflirane mrežne kompanije bili su uočeni na početku 1970-ih, što je dovelo da većeg broja istraga ne samo od strane Savezne agencije za trgovinu (Federal Trade Commission, FTC) nego i od strane Savezne agencije za tržište kapitala (Securities and Exchange Commission). Centralno pitanje je bilo kako i na osnovu čega razlikovati legitimne mrežne sisteme od kamufliranih piramidalnih šema. Odgovor, i dan-danas važeći AMWAY-test, bio je isto formulisan tada. Srž istoga je da ukoliko sistem ne opstaje isključivo od regrutovanja i finansijskih priloga novih članova, odnosno taj izvor prihoda nije dominirajući, smatra se da je konkretni mrežni sistem legalan.

Evropska unija se suočila sa istim pitanjem sa nešto zakašnjenja, ali odgovor je našla u formuli koja je slična američkim: takozvani '4finance UAB test', formulisan od strane Suda Evropske unije u Luksemburgu u 2014, u biti se zasniva na istim osnovama a vezanim za pravo o nepoštenoj poslovnoj praksi. Nažalost, s obzirom na to da gro sudskih presuda i odluka antimonopoliskih organa država članica Unije vezano za mrežne sisteme ostaju dostupne samo na lokalnim jezicima, a uz to mnogi i nisu pristupačni široj javnosti, malo se može znati o njima, iako bi bili jako interesantni za pravne sisteme koji sada planiraju da izrade svoju dotičnu regulativu. Na primer, nasuprot tradicionalnom poimanju mrežnih sistema kao sistema koji plasiraju na tržište kozmetičke proizvode (npr. AVON), u Mađarskoj dva propisno registrovana osiguravajuća društva su organizovala takav mrežni sistem ličnog osiguranja gde su se članovi mogli ne samo lično osigurati nego su dodatno mogli zaraditi i provizije putem regrutovanja novih članova. Po odluci antimonopolskog organa, a na osnovu, 4finance UAB` testa, radilo se o piramidalnoj šemi u kojoj su regrutacioni aspekti dominirali te su firme-organizatori bile novčano kažnjene a sistem zabranjen.

U afričkim, azijskim i latinoameričkim državama ovi problemi često imaju i dimenzije koje su nepoznate u Evropi, prvenstveno zbog nepostojanja sistema socijalnog osiguranja, nižeg životnog standarda, nepostojanja ličnih i porodičnih ušteđevina i velikog broja ljudi kojima su bankovne usluge nepristupačne. Najsiromašniji, sa malo izgleda da dobiju stalni posao, često u mrežnim sistemima vide prospekt nečeg nalik na radni odnos sa mogućnošću redovne zarade i zato se pridružuju. Kako često treba da ulože za učlanjenje, sve što mogu skupe od bližih rođaka, a kada izgube uloženo, ne samo oni lično nego i njihove porodice su dovedene u jako tešku situaciju. Ako lokalni finansijski 
i pravni sistem uz to još nije spreman da se suoči sa finansijskim pitanjima koje primena navedenih testova zahteva, reakcija je često zabrana svih mrežnih sistema bez razlike. To se dogodilo pre nekoliko godina na primer u Mijanmaru (Burma) ili na Šri Lanci.

S obzirom na to da testovi i iskustvo iz kojeg se može učiti postoje, glavna konstatacija članka je da nema razloga za odlaganje formulisanja pravne regulative o mrežnim sistemima, ni u Srbiji, ni u ostalim zemljama koje su još van Evropske unije. Pravila koja adekvatno balansiraju suprotne interese jesu ta formula koja će najviše pomoći potrošačima kao postojećim ili potencijalnim članovima mrežnih sistema.

Ključne reči: mrežni marketing, piramidalne šeme, gole piramidalne šeme, Ponzijeve šeme, regulativa finansijskih tržišta, zaštita potrošača, Emvej test (SAD), '4 finance UAB' test (Evropska unija), pravo Evropske unije. 